\title{
Theodor F.W. Holzdeppe Jørgensen in memoriam
}

\author{
Anders Holm og Kim Arne Pedersen
}

Det var ikke kun den særlige, i grundtvigske forskerkredse så velkendte, diktion, der røbede sønderjyden. Theodor Jørgensen var af sind og i hele sin livsanskuelse dybt præget af sin opvækst i det dansk-tyske grænseland, og dette blev udslagsgivende for en række af de emner, han tog op, da han midt i livet for alvor påbegyndte sine studier af Grundtvig og hans forfatterskab.

Som nyuddannet cand.theol. fra Københavns Universitet 1961 tog Jørgensen på to længere studieophold i henholdsvis Heidelberg og Zürich. Derpå blev han i perioden 1963-1969 tilknyttet Det Teologiske Fakultet i København, først som kandidatstipendiat og siden adjunkt. Herefter fulgte fra 1969 et virke som præst i folkekirken, inden han i 1974 blev professor i dogmatik ved Københavns Universitet - en stilling han bestred indtil pensioneringen i 2004, alt imens han var ulønnet hjælpepræst ved Helligåndskirken, sad i forskellige bestyrelser og tillidshverv og ofte optrådte som debattør i dagspressen.

Da Jørgensen i 1977 tre år efter ansættelsen blev doktor på afhandlingen Das religionsphilosophische Offenbarungsverständnis des späteren Schleiermacher, var der næppe mange, der forventede, at Grundtvig skulle komme til at indtage en betydelig plads i hans fremtidige forfatterskab. Når det blev anderledes - skønt Grundtvig vedblivende blot var ét blandt flere forskningsområder - skyldtes det givetvis, at Grundtvig som Schleiermachers samtidige for Jørgensen var en form for naturlig adgang til dansk teologi og en mulighed for at blive hørt i de teologiske og kirkelige sammenhænge, hvor linjer og fronter blev trukket op og lagt fast. Desuden blev en 
konkret ydre anledning igangsættende, nemlig Jørgensens deltagelse i Det Lutherske Verdensforbunds generalforsamling i Tanzania i 1977. Ved den lejlighed holdt han en forelæsning over emnet "Kulturel og kristen identitet som kristologisk problem", der udkom i bearbejdet form som artikel i tidsskriftet Fønix samme år.

I artiklen gør Jørgensen sig til talsmand for den såkaldt kontekstuelle teologi. Det vil sige en teologisk tænkning, der går ud fra, at kristendommen ikke i sig selv er kultur, men tværtimod kun kan få skikkelse i en allerede eksisterende kulturel og samfundsmæssig sammenhæng. En afgørende pointe i artiklen er, at den, der bliver kristen i en ikke-kristen kultur, ikke skal aflægge sig sin kulturelle identitet.

I tilknytning til Grundtvigs ofte citerede linje "menneske først, kristen så” når Jørgensen frem til, at der for den kristne i enhver given kultur hverken kan være "tale om et brud eller om et sammenfald mellem kristen og kulturel identitet" (3). Det afgørende er tværtimod "et dialektisk forhold imellem erfaring af menneskelighed og kristen erfaring” (5). Løbende fornemmes en genklang af Schleiermachers kristologiske tolkning af menneskets gudsbevidsthed, f.eks. når det hævdes, at den kristne identitet "er skjult i den kulturelle identitet" (8). Derigennem åbnes kristendommens universelle perspektiv, som eksempelvis er til stede "I al sin glans nu stråler solen", hvor alle modersmål skal smelte sammen i "Jesus-navnets offerskål” (14). Ganske karakteristisk forbinder Jørgensen endvidere sin Grundtvigtolkning med et forsvar for den økumeniske teologi, det fælles i kristendommen bag om forskellene mellem de forskellige konfessioner.

Set fra Grundtvigforskningen var det mest bemærkelsesværdige ved artiklen, at den fremkaldte et modindlæg fra Kaj Thaning (1904-94) allerede i 1978-delen af samme årgang af Fønix. Thaning karakteriserer selv sin artikel som en række "spørgsmål til Theodor Jørgensen" (240). I realiteten var der mere tale om et forsvar af hans egen tese fra disputatsen i 1963 om Grundtvigs adskillelse af kristendom og menneskeliv. I slutningen af 1970'erne havde Thaning i mere end et årti præget billedet af Grundtvig, ikke blot i forskningen, men i dansk kulturliv bredt forstået. Der er derfor intet underligt $\mathrm{i}$, at han følte sig nødsaget til at pointere, at Jørgensens tilgang for ham at se var en vildvej. For Thaning var anliggendet i Jørgensens artikel intet mindre end et brud på den implementering af adskillelsestesen som basis for kirke- og kulturliv, som han havde arbejdet på siden 1940'erne. 
I artiklen betones det, at det er fejlagtigt at forstå "menneske først, kristen så" som en fremadskridende udvikling eller proces, for "menneskelivet, Guds værk, er en virkelighed i sig selv - før det døbes" (240). Desuden mener Thaning, at der hos Jørgensen forekommer en umærkelig overgang "fra kultur til etik", hvorimod han selv opfatter Grundtvigs folkelighedsbegreb som et forsvar for "kærnen i Luthers forkyndelse, retfærdiggørelsen af tro". I indlægget mærkes her såvel Thanings nære forbindelse til K.E. Løgstrup som hans baggrund i tidehvervsbevægelsen.

Jørgensen svarede i den følgende årgang af Fønix under overskriften "Folkelighed og Kristendom" (38). Artiklens synpunkt er, at Thaning i sin tolkning sætter "skel mellem evangelium og folkelighed i stedet for at sondre mellem dem", og at han derved "river (...) skabelsesteologi og kristologi (...) fra hinanden" (39). Derved kommer han i modstrid med Grundtvigs anliggende, mener Jørgensen. Det samme sker, når den kristne frelse nedskrives til udelukkende at handle om syndernes forladelse. For Grundtvig betød inkarnationen i stedet, at Kristus får "indflydelse på vort menneskeliv" (40).

Debatten med Thaning mundede ud i Jørgensens formentlig vigtigste bidrag til Grundtvigforskningen, artiklen "Adskillelse og vekselvirkning" fra Grundtvig-Studier 1986, der af og til er blevet betegnet som et radikalt brud med Thanings tese. Mere præcist ville det dog nok være at tale om en videretænkning og nuancering. Jørgensens arbejde forudsatte nemlig Grundtvigs begreb om adskillelsen, som Thaning jo om nogen var den, der havde fremdraget. I hovedanalysen gennemgås de to artikler "Folkelighed og Christendom" og "Om Folkeligheden og Dr. Rudelbach" fra 1847 og 1848, hvor Grundtvig selv gjorde rede for, at han ikke sammenblander danskhed og kristendom og dog alligevel kan tale om vekselvirkning. Med tydelig adresse til Thaning, som dog aldrig nævnes ved navn i artiklen, fastslår Jørgensen:

Man har i de senere år talt meget om Grundtvigs adskillelse af folkelighed og kristendom. Vekselvirkningen dem imellem har man talt mindre om. Men adskillelsen bliver fejltolket hos Grundtvig, hvis man undlader at give vekselvirkningen den samme vægt som adskillelsen. For Grundtvig skiller så skarpt mellem folkelighed og kristendom netop for den frie vekselvirknings skyld (72). 
Enhver "sækularteologisk påberåbelse" (75) af Grundtvig eller Luther finder Jørgensen tvivlsom. Desuden gør han opmærksom på, at det helt afgørende for Grundtvig er, at der kan finde en fri vekselvirkning sted. Selv om folkelighed og kristendom aldrig bliver det samme, er de med Grundtvigs eget udtryk "i deres forskellighed ikke uforligelige" (75). Som Thaning vil Jørgensen dog heller ikke vide af en fast tidsfølge. Skønt folkeligheden er en forudsætning for, at kristendommen kan slå rod, er folkelighedens levendegørelse kun "optakten til og indledningen af vekselvirkningen" (78).

I denne vekselvirkning oplyses og frugtbargøres folkeligheden. Samtidig får kristendommen konkret skikkelse i et folk og formes heraf. Igen fornemmes den kontekstuelle teologi, ligesom man aner Jørgensens store interesse for Grundtvigs tanker om gudbilledlighed, vækst og det medfødte og det genfødte menneskeliv. Nogle år senere kunne han i artiklen "Kontekstuel teologi - set i sammenhæng med Grundtvigs teologiske ansats"1 endnu mere direkte konstatere: "Sandheden i det medfødte menneskeliv bevæger sig mod sandheden i det genfødte menneskeliv og bekræftes af den som sandhed" (56).

Der er, som antydet, ikke tvivl om, at også Jørgensens Schleiermacherstudier havde betydning for hans arbejde med Grundtvig, og han er vel stadig, om ikke den eneste, så blandt de meget få, der har sammenlignet de to teologer. I en anden artikel fra 1986, "Schleiermachers und Grundtvigs Verständnis vom Heil in Bezug auf die Versöhnungslehre unter besonderer Berücksichtigung ihrer Bestimmung des Bösen”, redegør Jørgensen for, at Grundtvig-Schleiermacher-sammenligningen skal tjene som et værn mod den dialektiske teologis fortrængning af den kristne tro til en ghetto "uden relation til menneskers øvrige livsverden" (126). ${ }^{2}$

Der påpeges desuden en lang række ligheder mellem de to teologiske tænkere, f.eks. i forholdet til oplysning og romantik, gudstjenesteforståelse og synet på statens og kirkens forhold til hinanden. Jørgensen forsøger dog især, som titlen siger, at sammenligne deres syn på ondskab, forsoning og

1 Fra: Kontextuell livstolkning. Teologi $i$ ett pluralistikt Norden, Religio, bd. 43, 1994, 43-56.

${ }^{2}$ Fra Hultberg, Helge m.fl., Schleiermacher - im besonderen Hinblick auf seine Wirkungsgeschichte in Dänemark, München, København, Wilhelm Fink, 1986, 82-101. Artiklen udkom på dansk i forbindelse med Jørgensens 60-årsdag i 1995 i antologien Korset i Altet, København, Forlaget Anis, 1995, 124-41. (Begge citater i afsnittet er fra Korset i Altet, 126). 
frelse. Den store forskel ligger i synet på det onde. I artiklen vender han sig med Grundtvig mod Schleiermachers "harmoniserende frelsesforståelse" (126). I forhold hertil foretrækkes Grundtvigs betoning af det onde som en reel værensmagt. Samtidig mente Jørgensen dog også, at Grundtvigs syn på forholdet mellem Gud og det onde rummer problemer. I konferencebidraget "Gott. Herr oder Sinn der Geschichte" fra 1988 fremføres f.eks. den anke mod Grundtvig, at sejren over det onde skygger for korset som fortegn for, at Gud i kraft af sit væsen som kompromisløs kærlighed selv lider i historien.

Det nok mest afgørende ligeløb mellem Grundtvig og Schleiermacher fandt Jørgensen i deres syn på gudbilledlighed og vækst og kirken som et afgørende sted for den enkelte. I artiklen "Guds sande menneske. Urbilledkristologi hos Schleiermacher og Grundtvig" "fra 1995 anvender han de to teologer som en påmindelse om ikke at glemme Jesu menneskelighed, som det sker i megen nutidig forkyndelse og kristologi - formentlig igen et hib til den dialektiske teologi. Jørgensen gør dog også opmærksom på en grundlæggende forskellig opfattelse af sakramenterne hos de to teologer. Med det som udgangspunkt rettes igen en kritisk brod mod Schleiermacher, der ikke som Grundtvig fastholder en kvalitativ forskel på Gud og menneske. Schleiermacher savner ganske enkelt Grundtvigs forståelse af Kristus som levende til stede i gudstjenestens ord, mener Jørgensen.

For en professor i dogmatik var det naturligt, at det var Grundtvigs salmer og den kirkelige og teologiske side af forfatterskabet, der gennem årene fik den største opmærksomhed. Det gjaldt især Jørgensens undervisning på Det Teologiske Fakultet, hvor "Kirkelige oplysninger især for lutherske Christne" og Den Christelige Børnelardom var blandt yndlingsteksterne. Men også flere af hans artikler om Grundtvig bestod af forholdsvis tekstnære tematiske studier af teologiske hovedværker, som ofte kombineredes med diskussioner af nutidige og principielle dogmatiske spørgsmål.

Et eksempel herpå er artiklen "Grundtvigs 'Kirkens Gienmæle' - læst i et nutidigt perspektiv" fra Grundtvig-Studier 1992, hvor Grundtvigs kampskrift fortolkes ud fra en række nutidige bestemmelser af troen.

3 Fra Zobel, Hans Jürgen, Gott und Geschichte, 25. Konferenz der Hochteologen der Ostersee, Greifswald, 1988. Artiklen udkom ligeledes på dansk i 1995 i Korset $i$ Altet, 46-58.

${ }^{4}$ Fra Hartman, Lars, m.fl. Jesustolkninger i dag - tio teologer om kristologi, Stockholm, Verbum, 1995. 
Det, Grundtvig dybest set peger på i sit berømte kampskrift, er, fremføres det, at troen er en erfaringssag, en vishedssag og et spørgsmål om identitet. Netop erfaring, vished og identitet er, hvad mennesket opnår i gudstjenestens sammenhæng. Det er ifølge Grundtvig teologiens opgave at udrede dette, hævder Jørgensen. Grundtvigs synspunkt er dog, at der blandt teologerne altid vil være forskelligheder og modsætninger på færde, da forskellige sammenhænge og tider kræver nye fortolkninger. På den baggrund gøres der atter opmærksom på lighederne i anliggendet mellem Grundtvig og den kontekstuelle teologi.

Ligeledes blev det økumeniske perspektiv ved med at gøre sig gældende i Jørgensens arbejde med Grundtvig. Således f.eks. i artiklen "Grundtvigs økumeniske Helligåndsteologi" fra 1993 hvor en række ansatser fra tidligere studier føres videre, men nu - som det var karakteristisk for Jørgensens arbejde i de senere år - med en mere kritisk holdning til bestemte dele af Grundtvigs teologi. Især påpeges det, at Grundtvig i nogle tekster synes at identificere Helligånd og menneskeånd og dermed Helligånd og folkeånd. Dette fører ham, påstås det, i retning af en nationalisme, hvor kristendommen legitimerer og tjener en regionalt og konfessionelt begrænset kultur. Undervejs indrømmer Jørgensen dog indirekte, at de gjorte iagttagelser hviler på et noget spinkelt tekstgrundlag, idet det beklages, at undersøgelsen lider under savnet af en fyldestgørende monografi om Grundtvigs Helligåndsteologi.

Til trods for dette økumeniske perspektiv var Jørgensen på ingen måde blind for, at Grundtvig forstod sig selv som luthersk. Dette kom til udtryk i en hel del artikler både på dansk og tysk. Nævnes skal især "Grundtvig og den Lutherske tradition" fra Grundtvig-Studier 1998, hvor Jørgensen foretager en udførlig gennemgang af tredje del af "Skal den lutherske reformation virkelig fortsættes?”. Med de reformatoriske eksklusiv-partikler sola fide, solus Christus og sola scriptura som pædagogisk folie for sin læsning gøres rede for, hvordan Grundtvigs opgør med det lutherske skriftsyn i grunden samtidig er en tilslutning til Luthers genindsættelse af troen som kristendommens centrum. En central pointe i artiklen er endvidere, at Grundtvig skelner mellem trosliv og troslære, og at han til forskel fra de fleste andre konfessionelle traditioner - herunder den lutherske - ikke

${ }^{5}$ Fra Thomsen, Henning, Du som går ud fra den levende Gud. Bibelteologiske og teologihistoriske overvejelser over helligånden, København, Anis, 1993, 70-84. 
placerer kætterbegrebet i læren, hvilket overalt får meget stor betydning for rummeligheden i den kirkeforståelse, der vokser ud af hans anskuelser. Endvidere gør Jørgensen rede for, at hans mål med artiklen er at befri Grundtvig "fra luthersk og dansk omklamring” (44). Også denne målsætning, der måske lidt paradoksalt forudsatte Grundtvigs centrale betydning i dansk åndsliv, var kendetegnende for Jørgensens sene arbejde med Grundtvig.

Som sagt udkom en hel del af Jørgensens artikler på både dansk og tysk, hvilket peger på en af Jørgensens nok største ambitioner i arbejdet med Grundtvig; at gøre ham bedre kendt i Tyskland. Den mest betydningsfulde indsats i den henseende blev det store oversættelsesprojekt i samarbejde med K.E. Bugge og Flemming Lundgreen-Nielsen, som det efter årtiers samarbejde lykkedes at fuldføre i 2010 som udgivelsen: N.F.S. Grundtvig: Schriften in Auswahl. Denne 942 sider lange tyske Grundtvigudgave i tre dele vil på grund af de kompetent udvalgte, oversatte og kommenterede tekster i de næste mange år være det naturlige udgangspunkt for tyske teologers, skandinavisters og højskolefolks arbejde med Grundtvig og er også for danskere i flere henseender fuld af nyttige oplysninger. 